\title{
PICTORIAL AND VERBAL TEXTS: COEXISTENCE, TRANSFORMATION, COOPERATION
}

\section{Kolegaeva I. M.}

\section{INTRODUCTION}

The world is three-dimentional, polychrome, dynamic and acoustically variable. It can be reflected verbally through description of all dimentions, colours, movements, sounds etc. It can also be, among other numerous possibilities, depicted through colours and lines on a canvas, a sheet of paper or a wooden board. Neither variant is the world as it is, but a certain message about the world. The point is whether both these messages can be treated as texts? There are no debates about a verbal message. But what about a pictorial message?

The colours and lines on a flat surface of a picture create an illusion of a fragment of the three-dimensional dynamic world which the on-looker is presumably viewing through the frame of the picture. "Western art had been, from the Renaissence up to the middle of the 19th century, underpinned by the logic of perspective and an attempt to reproduce an illusion of visible reality" (Hereinafter emphasis is mine - I.K.). The illusion mentioned is true at least when we deal with a piece of figurative painting. Whether it is true of a piece of abstract, surrealistic, cubistic or any such type of painting is yet to be discussed, so much so as "abstract art, non-figurative art, non-objective art, and nonrepresentational art bear no trace of any reference to anything recognizable"2.

Marion Boddy-Evans emphasizes that "realism is the art style where the subject of the painting looks very much like it appears in real life, (while) pure abstract art does not try to look like anything from the real world" ". At the same time there is a certain degree of conventionality (commonly accepted) in a realistic picture and it is rather obvious, for example, if the picture is monochrome. Lack of colours does not imply unrealistic key of such work.

Furtheron we discuss figurative painting only and regard its semiotic and communicative potential. One of the founders of semiotics Charles Morris believed that painting as much as speech should be regarded as a

\footnotetext{
${ }^{1}$ Leys S. The Hall of Uselessness : collected essays. e-Book : English/ 2012. : Collingwood, Vic. : Black Inc. 2 ibid.

3 Boddy-Evans M. Abstract Art : An Introduction. URL: http://painting.about.com/od/abstractart/a/ abstract_art.htm
} 
sign system. Thus, a picture should be regarded as a semiotic phenomenon, namely a text ${ }^{4}$.

Yuri Lotman while meditating upon semiotics of culture was adamant about differentiating and even opposing to each other the two types of semiotic messages (texts in his terminology), namely, discrete verbal texts on the one hand and non-discrete, continual texts like pictures. He believed that translations from one type of text into the other (from a picture into a verbal text) or vice versa were impossible. But as far as they happen once and again, $\mathrm{Yu}$. Lotman concluded that such attempts result not in translations but in equivalent versions of each other ${ }^{5}$.

In my humble opinion, it is more the issue of terminology than the essential difference. I stick to the term transformation, in a broad sense. My view point is the following.

First: both a picture and a verbal message are texts.

Second: they can share a common message, a) either functioning by itself each, b) or citing each other, d) or transforming each other.

Third: a complete message can be a visual transformation of a verbal message and vice versa.

Fouth: a verbal text can and usually does comment upon a visual text, but not vice versa.

And fidth: a pictorial message can be verbally transformed and incorporated into a verbal text as its part of it but not vice versa.

\section{Transformation}

A complete pictorial message can be nothing but a visual transformation of a verbal message. The samples of such are numerous pictures which visualize a certain episode from The Bible or from ancient mythology. For example, everybody remembers The Biblical episode "Adoration of the Magi" (sometimes "Gifts of the Magi"). It was re-created, visualized, or in our terms transformed into dozens and dozens of pictorial versions of the message. Just to name the most outstanding painters (in alphabetical order - to make it neutral): Hieronymus Bosch, Sandro Botticelli, Peter Breugel the elder, Albrecht Dürer, Giorgione, Peter Paul Rubens, Diego Velázques, Lenardo da Vinci, and many others.

The episode from ancient mythology narrating about Hercules who had to choose between Vice and Virtue "Hercules at the Crossroads" is transformed into quite a number of pictures (in historical perspective):

\footnotetext{
${ }^{4}$ Моррис Ч. У. Основания теории знаков. Семиотика : Антология. Сост. Ю.С.Степанов. 2-е изд. испр. и доп. М. : Академический проект, 2001. С. 45-97.

5 Лотман Ю. М. Семиотика культуры и понятие текста. Структура и семиотика художественного текста. Труды по знаковым системам. Ученые записки Тартуского гос. университета. Тарту, 1981. Вып. 515. С. 3-7.
} 
the XV c. - Girolamo di Benvenuto; the XVI c. - Johann Liss, Annibale Caracci; the XVII c. - Peter Paul Rubens, Jan van den Hoecke; the XVIII c. - Paolo de Matteis, Benjamin West.

The pictures mentioned of course differ from one another in everything but a) the narrative plot, b) the system of personages, c) the collision visualized. It is worth noting that except the title of the picture there are no verbal links between the "initial" verbal texts (the Bible, mythology) and its visual equivalents.

Thus, we observe the case of multiple inter-code transformations of a single complete verbal message into its equivalent pictorial versions (In Yu.Lotman's terminology). The opposite vector of transformations (pictorial text into verbal) is also registered rather frequently. Such verbal texts vary in their stylistic attribution and their pragmatic goals. Most often it happens in belles-lettres writing. Part of a verbal message turns to be a transformation of a pictorial message. Belles-lettres texts readily include a picture not only as a detail of interior description, but as sort of a "character" or at least some "source of plot development".

To mention but some of them: O.Wilde's famous "The Picture of Dorian Gray" and his less famous "The Portrait of W H", the well known novels by D. du Murray "Rebecca" and "The Moon and Sixpence" by S. Maughm, the shortlist Booker Prize nominee of 1999 M. Fray's "Headlong" and many others. The pictures in those books are treated as messages with vitally important content, iconically encoded by fictitious artists, and transformed into verbal messages by the authors of the novels.

Obviously, no picture is presented, yet the reader is "looking" at the picture, "examining" its minute details. But unlike the real on-looker in a picture gallery, who grasps the visual message holistically and simultaneously, the reader-on-looker perceives the picture, in a linear succession of one by one details chosen for him by the writer. Such are the inevitable limitations of transforming a pictorial, iconic message into a verbal message. The reader of such text, who turns into imaginable viewer, can "see" what is shown to him. And it is not his selection: which of the picture's aspects should be inspected more scrupulously than the others (for more details see my publication ${ }^{6}$ ).

\section{Coexistence}

A pictorial text and its verbal equivalent might coexist side by side at the common trerritory of a polycode message. Sometimes visual and verbal

\footnotetext{
6 Колегаєва I.M. Полімодальність відчуттів у дзеркалі полікодовості тексту, або ще раз про антропоцентризм у лінгвістиці. Записки з романо-германської філологї. Випуск 2 (35). Одеса : КП ОМД, 2015. C. $105-113$.
} 
phenomena (each exploiting different codes) share "the territory" of a common message. The name for such heterogenous message is polycode text.

The coexistence mentioned can happen in two variants.

Variant A. Each heterogeneous component of a polycode text functions on its own. Usually it is a verbal text with incorporated pictures, schemes, maps etc. We meet such in belles-lettres and academic writing, in travel and adventure stories, and guide books. Pictorial messages here may function as citations: narration tells about some letter, or scheme, or map, and the letter, the scheme, the map is presented to the reader in their authentic or imaginary authentic form. Each heterogeneous component of a polycode text might as well function completely on its own. The overwhelming prevalence of a pictorial component over a verbal component brings out such polycode text as a comic strip (sometimes even a comic book). The point to be emphasized here is that each of the messages (verbal and pictorial) functions in a polycode text to a certain degree "on their own", transferring their own pack of information and eventually creating the common communicative whole.

Variant B. The heterogeneous components of a polycode text function as tranformations of each other. The example is a book with illustrations, each illustration repeating what was already told in words, this time "re-telling" the episode from the book in pictorial form. To name the brightest examples: John Tenniel's illustrations to L.Carrol's "Alice's Adventures in Wonderland" and "Through the Looking-glass" or Ernest Shepard's illustrations to A. Milne's "Winnie-the-Pooh". It should be emphasized that pictorial transformations of the book's episodes are communicatively "one way road": the text has no explicit references to the illustrations. The only connectors are captions (sometimes a phrase from the text, sometimes just a general nomination of the situation) which might follow the illustrations. In a way it resembles the situation of pictorial visualization of Biblical/mythological motive. The difference lies in their dual (pictorial and verbal) presentation (side by side) to the addressee. The presence of illustrations enhances the communication (especially in children's reading community). But definitely, the absence of illustrations does not deteriorate the communication, to say nothing of communicative failure.

\section{Cooperation}

In some sort of polycode texts which incorporate both pictorial and verbal messages independent presentation (coexistence) of each of them does not imply independence of their functioning. Most obviously it happens in such specific type of polycode texts as museum catalogues. 
The analysis of a picture gallery catalogue ${ }^{7}$ (all further references are to this publication) showed that a catalogue article is a twofold message, comprising a pictorial and a verbal component. The former being a reproduction of some famous picture, the latter being approximately 150-200 word long annotation commenting upon the painting, the artist, sometimes the history of the picture, its artistic and literary background. The two components are unequal as to the degree of self-sufficiency in the process of their perception. The pictorial component might presumably function independently, though with certain loss of its informative potential. The verbal component is nearly useless in case it is devoid of the corresponding pictorial support. In other words, an addressee of a catalogue may more or less successfully leaf through the catalogue without reading the textual messages, but an addressee cannot just read the annotations and skip the illustrations. The result will be a communicative failure.

Let us consider the unfavourable position of a catalogue user who only looks at the reproduction (suppose he/she does not speak the language of the annotations). To begin with, the reproduction is for sure the first to catch the eye, yet it does not contain exact information of the picture size, which is by far different from what the addressee sees in the catalogue.

Our research proved that the size of a picture is decreased drastically: a reproduction sometimes equals as little as $0.2 \%$ of the space which the original canvas occupies. No doudt the impact upon the on-looker is manifolding weaker. The reader of the catalogue is usually quite unaware of this difference. The verbal component of the catalogue article cooperates with the pictorial component and informs the reader about the original dimensions of the reproduced picture, giving the exact figures.

Sometimes the dry figures are "revived" in the annotation through a descriptive commentary. For instance, "The Still-life" by France Snyders is nearly 2 meters high and more than 3 meters long, its reproduction is more than 200 times smaller. The annotation revives the largeness of the canvas, saying: "The huge size of the still-life indicates a certain type of client with large rooms available, like nobility with castles and large dining-rooms".

The descriptive details like "huge size" "large dining-rooms", "castles" help the reader visualize the hugeness of the original painting, enhancing the precise data of the passport: " $1,97 \mathrm{~m} \mathrm{x} \mathrm{3,25} \mathrm{m".}$

In some cases the cues that help the addressee imagine the real dimensions of a picture are given in the annotation indirectly, through a detail. Titian's famous picture "The Tribute Money" is commented upon as following: "Titian painted this magnificent painting of Christ... on a

\footnotetext{
${ }^{7}$ Masterpieces of Dresden. Picture Gallery “Old Masters”. By H.Marx. Leipzig : E.A.Seeman, 1993. 62 p.
} 
wardrobe door in the castle of Ferrara" ${ }^{\prime \prime}$, thus highlighting the passport information: " $75 \mathrm{~cm}$ x $56 \mathrm{~cm}$, Oil on poplar wood". It is much easier for the addressee to visualize the size of the picture knowing that it used to be a part of a wooden wardrobe.

Another type of cooperation between verbal and pictorial messages lies in explaining to the reader of the catalogue what the picture is about, especially if the reproduction belongs to the so called "narrative painting". The addressee, functioning exclusively as an on-looker, has to guess who is who in the picture and what's happening in the imaginary world of the painted message. Much depends on the addressee's cultural thesaurus. In case of certain deficiency of cultural knowledge, the informative impact of the picture upon the on-looker is considerably weakened. A helping hand is thrust forward by the annotation author, who provides the addressee with all the information required for the adequate perception of the visual message.

For instance, Nicolas Poussin's picture "The Kingdom of Flora" is a visual "transformation" of literary texts by the antique Roman poet Ovid. The annotation explains, that "the flower goddess is dancing in the centre, surrounded by figures which were transformed after death into flowers", then each of the 7 characters is named (they are Klytia, Narcissus, Smilax and Crocus, Adonis, Hyacinth and Ajaks). Their position in the picture is defined, as well as the position of the flowers, into which they will be transformed after death, and the names of the flowers are also given (correspondingly, they are heliotrope, daffodil, bindweed and crocus, anemone, hyacinth and pink). The amount of additional information encoded verbally and offered to the addressee of the museum catalogue is very big. It is unlikely that many visitors of Dresden Old Masters gallery, looking at Poussin's picture can enjoy as large scope of information as the addressee of the catalogue "Old Masters".

While re-telling "what is going on" in the picture, the annotation also comments upon certain features of the painting: its symbolic details, its colour range, its composition and the like. Each commentary of such type makes the reader turn his/her gaze upon the picture reproduction. For instance, the commentary of Pieter Glaesz's "Still-Life" explains to the addressee that "The pocket watch with opened lid was meant as a hint to the inexorable passing of time". The passage induces the reader to look again at the reproduction and find the symbolic detail which he might have missed before.

Comments like the following: "his colours are elegant and very delicate", "the tendency to uniform hues"; "delightful blooming colour"

\footnotetext{
${ }^{8}$ Masterpieces of Dresden. Picture Gallery “Old Masters”. By H.Marx. Leipzig : E.A.Seeman, 1993. P. 15.
} 
make the reader turn his eyes to the picture and see for himself whether the colours are blooming, elegant and delicate and whether there is the tendency to uniform hues.

What is important - the colour nominations per se are not used: green, red, yellow are superfluous, as the picture is at hand and the colours are exposed to the on-looker ${ }^{9}$. Meanwhile, the annotation offers qualifications of the colours (fresh colours, subtle hues, surprisingly colourful), thus suggesting certain interpretation of the picture.

The effect of perspective is one of the means of creating the optic illusion of three-dimensional world on a two-dimensional flat surface of a picture. Annotation helps the reader comprehend this peculiarity of painting, drawing his/her attention to the correspondence of foreground and background, as is in Jan Wildens's "Winter Landscape with Huntsman": "the figure of the hunter is the main focus; the landscape stands in the background...a great suspense exists between things of the foreground level and the expanse of the wintry space which is lost in the depth". This is another reason for the addressee to look back at the reproduction and see for himself whether the effect of depth is created by the painter.

Thus, cooperation of pictorial messages (schemes, maps, illustrations, reproductions) and their verbal companions in a shared mrssage can be multiple and variable, with different communicative aims and results.

\section{How it works in museum catalogue article as a polycode text}

The museum catalogue we are presently analyzing is Masterpieces of Dresden. Picture-gallery "Old Masters" $(1993)^{10}$. It is the English version of the catalogue comprising polychrome reproductions of most outstanding pieces of art and commentaries to each of them.

While discussing coexistence of pictorial and verbal components of a polycode text in a museum catalogue it is worth noting that both of them are located in a common visual field. This means that the user can view each reproduction and read its verbal commentary without turning the pages of the catalogue. Each polycode text here is a self-sufficient communicative item.

Cooperation of pictorial and verbal messages in such text may result in two effects: either enriching the addrressee's cultural thesaurus or enhancing the addrressee's communicative activity in his/her adequate perception of the pictorial component, namely, the reproduction.

\footnotetext{
${ }^{9} \mathrm{NB}$ ! We speak about polychrome reproductions, though sometimes monochrome ones also function

${ }^{10}$ Masterpieces of Dresden. Picture Gallery "Old Masters". By H.Marx. Leipzig : E.A.Seeman, 1993. 62 p.
} 
The first effect implies offering some pieces of information (presented in the annotation) which is usually called "vertical conext" of the corresponding canvas. In such cases the annotation reports: by whom, when and within which artistic school the picture was created. Besides, the added information concerns the personality of the painter: his biography and his artistic evolution and also some facts from the history of the canvas creation, difficulties (if any) in attribution of the picture etc.

The passport of the canvas preluding each annotation gives the painter's name and pseudonym (if any), the time and place of his birth and death. While death data are usually accurate; birth data may be approximate: "Pinturicchio, originally Bernardino di Betto, called Pinturicchio (around 1454 Perugia - 1513 Sienna)"; "Titian, originally Tiziano Vecellio, called Titian (approximately 1488/90 Pieve di Cadore 1576 Venice". The curriculum vitae mentioned in the annotations accentuate first of all, the creative personality of the artist in question. The reader will find out in which workshop the artist studied and worked: "Wildens was an assistant of Rubens, often painted landscape backgrounds for Rubens figure compositions"; what role other painters played in his work: "Snyders achieved his special talent after Rubens, who was a friend of his (as was van Dyck)"; "Philips Koninck was influenced by Hercules Seghers and Rembrandt".

Less frequently the opposite is mentioned: the influence of the author of the annotated canvas on the subsequent evolution of painting: "Domenico Fetti influenced the Venetian style of painting after the end of the 16th century". The annotation occasionally emphasizes the uniqueness of the artist's creative manner: "Vermeer was the only Dutch painter of the 17 th century whose style was not connected to any school of painting".

The museum catalogue we are analyzing describes the canvases of Dresden Gallery, collected in the so-called "Old Masters" collection. The history of these paintings covers several centuries. No wonder that the issue of attribution of the canvas is very often mentioned in the annotation. Each tenth annotation discusses previous erroneous attribution(s) of the canvas: "The Adoration of the Magi" by Francesco Francia "was regarded at the Gallery in the beginning as a painting of Perugino"; "The Meeting of Jacob and Rachel" by Palma Vecchio "was until 1880 mistaken as a work of Giorgione"; "Portrait of a Man" by Velasquez" reminds one of Titian under whose name it appeared in the gallery".

The history of the canvas creation frequently becomes the subject of discussion in annotations. Mentioned are the names of customers and sometimes the long path that the painting went before it entered the collection of Dresden Gallery: "Raphael created "The Sistine Madonna" 
around 1513 for the main altar of the monastery church San Sisto in Piacenza. The order came from Pope Julius II"; "Landscape" by Claude Lorraine "was painted on the order of a Lyon customer, but turned up in various Paris collections and finally in the collection of the Saxon envoy to the French court, Ch.H. Count Hoym, who bought it for the Dresden gallery".

Explications of "intertextual" connections of the annotated canvas with the artworks of other artists also expand the horisons of the addressee's cultural thesaurus. Approximately every fifth annotation contains a reference to some other canvas, or to the creative manner of another artist, or to another school of painting, or even to a literary text.

For example, the annotation which comments on Piazzetta's canvas "The Young Colour-Bearer" draws parallels not only with some other paintings: "Delacroix and Courbet would have found for him a place in a scene of commune", but also refers the user of the catalogue to the image of a literary character - the famous Gavrosh from Victor Hugo's novel "Les Miserables": "This boy is a relative of Gavroche on the barricades".

The catalogue user, who just speaks the language of the publication and lacks some background cultural knowledge, while perceiving such informational content, remains exclusively in the role of the reader, replenishing his/her thesaurus in the field of art history. The reader, whose thesaurus already contains the knowledge, on which the author of the annotation relies, can mentally compare the described picture with the canvases mentioned and find out some "intertextual" connections between them. Such cognitive activity, of course, enriches the entire process of communication. The user of the catalogue who does not speak the language of the publication simply does not take part in this communication enjoying only the reproductions per se.

We have already mentioned that cooperation of pictorial and verbal messages in a polycode text of the catalogue may result not only in enriching the addrressee's cultural thesaurus. Besides this such cooperation may and does enhance the addrressee's communicative activity in his/her adequate perception of the pictorial component, namely, the reproduction. It is achieved through the so called echphrasis which means "description of a work of fine art in a literary text"11. In annotation echphrasis often means transformation: giving the information about the picture's plot, persons involved and some other details.

\footnotetext{
11 Лотман Ю. М. Семиотика культуры и понятие текста. Структура и семиотика художественного текста. Труды по знаковым системам. Ученые записки Тартуского гос. университета. Тарту, 1981. Выпуск 515. С. 3-7.
} 
Having read the corresponding part of the annotation, the catalogue user examines the reproduction with greater interest, looking for confirmation of what has been said in the annotation. Commenting on the informative aspect of the painting, the annotation retells the plot, if the picture is a sample of "narrative painting" (mainly they are Biblical or mythology stories), explains what kind of character is depicted on the canvas, what he is famous for.

For example, the comment to Jusepe de Ribera's canvas "Saint Agnes" explains that Saint Agnes was exposed naked as an act of persecution for her Christian faith. But "she wrapped herself in her hair until an angel brought her cloth to cover herself". Having read such plot description, the catalogue user is scrutinizing a female naked kneeling figure with long flowing hair, wrapped in a veil, which is descending from heaven, and the situation depicted on the canvas obtains additional shades of meaning. For the catalogue user, who does not know the corresponding biblical episode, the title of the canvas - "Saint Agnes" is not informative enough and thus the canvas' emotive impact is much weaker.

Echphrasis, or verbal presentation of a picture is often followed with contemplations upon who was or migh thave been the prototype (who sat as a model) for the personage shown in the picture. The annotation sometimes contains some such information even about biblical personages.

For example, the annotation to Raphael's "Sistine Madonna" clarifies that it is Pope Julius II depicted in the image of St. Sixtus: "St. Sixtus has a resemblance to Pope Julius II, because the acorn at the top of the tiara is part of the coat of arms of the family Rovera, from which Julius II descended". The decoration of St. Sixtus' tiara is rather informative and as such is foregrounded and explained in the verbal description of the picture, thus tracing the personage's connection with its prototype.

Talking about Bartolomeo Murillo's canvas "Madonna and Child", the author of the annotation points out that in the image of Madonna there is a resemblance to a real noble lady: "Mary allegedly resembles Dona Maria de Leganés and this painting is therefore often called "Madonna Leganés".

The title character of Rubens' painting "Bathseba", according to the annotation, embodies the traits of the painter's wife: "One can feel in this painting, like in all women Rubens painted after 1630, that his second wife, Hèléne Fourment, was his model".

The fact that the catalogue user has never seen prototypes of the characters depicted on the canvas is not relevant. The presentation eventually acquires a certain note of intimization, which attracts the readerviewer. 
Sometimes verbal support of portrait content is limited to nothing more than the title of the picture indicating the name and social status of the person shown. For example, Rosalba Carriera's "Portrait of the Countess Anna Katarina Orzelska" or Lucas Cranach the Elder's "Duke Henry the Pious and his Wife, Catherine of Mecklenburg." Sometimes the title explicates nothing but the jenre of the painting, namely, portrait, adding (if any) some information about the details of what is shown in the picture, for example, Pinturicchio's "Portrait of a Boy" or Titian's "Portrait of a Lady in White", or Bernardo Strozzi's "Girl with a Viola da Gamba".

Verbal comments to the portrait reproductions may offer some psychological interpretation of biographical data of the person who sat for the portrait, since it is assumed that the portrait reflects all the characteristic features of the depicted person. For example, the comment on Quentine de la Tour's "Portrait of Maurice of Saxony Marshal of France" is nothing but a brief life story of Maurice Earl of Saxony, his military successes and victories. The annotation ends in the following passage: "He was not only a soldier but also a man of the salons, educated, clever and a friend of Voltaire and Marquise de Pompadour. The painting by De La Tour emphasizes this side of his personality".

Cooperation and support of a verbal component in a catalogue item is especially interesting in terms of communicative tactics employed in such polycode texts. In addition to the tactics of storytelling (description of the plot, the personages etc) mentioned above, certain tactics of emphasizing some fine and important details of the painting are widely used here.

Such tactics is involved, for example, in the annotation to the famous painting by Lyotard "The Chocolate Girl" (Jean-Etienne Liotard "The Chocolate Girl"), where the effect of light transmission is commented: "The painting... is illuminated through two windows, which reflect in the glass". The reproduction at the catalog page is only $25.5 \times 15.85 \mathrm{~cm}$ large. The detail mentioned in the annotation is an image of a glass of water on a tray which the girl holds in her hands. On the glass walls (its height in the reproduction is $16 \mathrm{~mm}$ ) there are two tiny reflections of the windows through which the light supposedly falls on the figure of the girl; there is no image of the windows as such on the picture. The likelihood that a viewer while looking at the reproduction will pay any attention to this detail is negligible. The author of the annotation resorts to the tactics of involving the addressee in the active process of perceiving everything in a multi-code message, forcing the reader-viewer to look more closely at what is depicted in order to better perceive what is said.

Some details of the canvas, reproduced in the catalogue, can, at least hypothetically, be seen by the viewer on their own, without any help of the 
text annotation. However, there is some information which, in principle, is not accessible to the viewer. For example, only the reader of the annotation to Joos van Cleve's "The Small Adoration of the Kings" receives the information that there is the artist's image on the canvas, i.e the figure of the painter himself: "The painting contains the self-portrait of the master... in the center, behind the parapet, one hand in front of his chest, pushed into his coat". The multi-figure composition of "worship of the Magi" in the foreground depicts Mary and the baby, Joseph and the three Magi. On the background there are the figures of three male characters who watch offering gifts to the newborn Jesus. One of the figures is a self-portrait of the artist, which can be recognized due to the details mentioned in the annotation: the man stands behind the parapet, his hand is thrust behind the lapels of his frock coat.

The search for this figure on the canvas is stimulated through the communicative tactics used in the annotation. The tactics aims at switching the recipient from one communicative role to another: the reader becomes a viewer of the reproduction. It is self-evident that only the addressee of this polycode text receives such information.

Another informational "bonus" to the addressee-reader-viewer, inaccessible to the addressee-viewer (only), is information about what was depicted on the canvas earlier but is no longer on it. For example, the annotation to Giorgone's "Sleeping Venus" tells the reader that in the painting created in the 16th century, several changes were introduced three centuries later: the figure of Cupid, who admires the sleeping Venus, vanished in the 19th century: "A cupido, which was sitting in former times worshipping the Venus is now only discernible through X-rays. The hardly recognizable remains were painted over in the 19th century".

Rembrandt's widely known painting "Self-Portrait with Saskia", according to the author of the annotation, initially not only had a different name but a different format (horizontal, not vertical, as it is now). The history of origin of this painting is complicated. It was designed in landscape format and based on biblical motive with many figures. Its title was "The Prodigal Son in a Tavern with Prostitutes". "The painting was later cut down on the left hand side by Rembrandt, as a result of which the upright format originated", the title became "Self-Portrait with Saskia". No chance of obtaining this packet of information for the viewer of either the reproduction or the picture per se, unless the viewer turns to the verbal comment of it. The addressee-reader-viewer of the museum catalogue becomes aware of some details from the history of the canvas creation, which are inaccessible to the addressee-viewer. 
Another example is the annotation to Jacob Jordans" "The Family of Christ at the Sepulcher" which reports that the painting after its creation was altered by the author (in art history such alterations are terminologically named pentimento ${ }^{12}$ ) under the influence of a Caravaggio's painting. The consequence of this influence, the annotation says, is not only the change of emotional tonality of the picture, but also its composition, namely: tonality became more restrained, and the image of the grave disappeared from the composition. "This early painting was later partly painted over by the painter and displays clearly the influence of Caravaggio's "Entombment of Christ", which... led to use such restrained and dignified expressions in his painting style. The figures display "composure". In connection with Caravaggio's composition also arises the impression that on the left hand side the grave with the body should follow". Such information prompts the reader to view the picture more carefully, perhaps wondering how the picture could have looked before the alterations.

Communicative tactics of involving the reader into contemplation of the annotated canvas shows itself in a variety of verbal markers. Such markers are references to the "observer" figure, with which the catalogue reader identifies himself: "The observer can feel in front of this painting..."; "The observer is reminded in front of this painting that Annibale Caracci was overwhelmed by the paintings of Veronese".

Inclusive "we" and generalizing "one" function as such markers too: "we see on this painting the rebirth of antique architecture"; "The landscape speaks to us in much quieter shades"; "Our painting was listed in" Liber Veritatis as number 110"; "After close inspection one can notice under plain features, deep thoughts and feelings".

Not only personal, but also temporal and, especially, spatial deixis in the text of the annotation is a powerful means of engaging the reader's contemplation of reproduction. Adverb here, demonstrative pronouns this, these denote the annotated canvas: "this painting / portrait / picture / pastel" or what is depicted on it, "this Madonna / panoramic view / silence". "This picture", "this portrait", "this canvas" are mentioned in the text of the annotation, emphasizing the spatial proximity of the readerviewer and the paintings presented in reproductions in a common visual and thus spatial field with text.

We suggest several interesting observations on "shifter words" which expose the position of a focalizer and mark the role of the addressee in his/her perception of space, depicted on the canvas.

${ }^{12}$ Моррис Ч. У. Основания теории знаков. Семиотика: Антология. Сост. Ю.С.Степанов. 2-е изд. испр. и доп. М. : Академический проект, 2001. С. 45-97. 
As is well known, the anthropocentric conceptualization of space along the axis "right $\longrightarrow$ left" (as well as along the axis "in front $<\longrightarrow$ behind") implies the figure of the focalizer, i.e. a person perceiving a certain locus. According to annotation texts, such focalizer may or may not be the reader who is interpreted as the viewer of the reproduction. The two axes function differently.

The axis "in front $\longrightarrow$ behind" is fully realized in the closed framework of the depicted locus in which the implied focalizer is situated. NB! For the viewer who is looking at the picture, everything what he sees is "in front" of him. This fact is not reflected. Instead, the spatial axis "in front $\longrightarrow$ behind" focuses on the character's figure or some other noticeable detail of the locus shown in the picture.

The function of "right $\longrightarrow \longrightarrow$ left" axis in polycode texts varies.

Compare the following. The annotation to Poussin's multi-figured picture "The Kingdom of Flora" informs the reader and viewer about who exactly is depicted on the canvas. To facilitate the search for relevant figures, the author indicates their spacial coordinates: "Behind Ajax, in front of trees entwined with festoons, is a statue of the futilitygod Priapus". The reference points in this spatial axis are the depicted Ajax and trees.

The reference point of the spatial axis "right $<\rightarrow$ left" is usually implicated to be in the locus of the viewer and sometimes (very rarely) it is placed in the locus of the depicted world.

The shifter words "right", "left", which concern the canvas (and its frame) as a whole, are oriented only upon the viewer's position: "The afternoon sun shines from the right hand side"; "The biblical theme is displayed at the left edge of the painting and the small figures are disappearing in the dark forest".

A curious situation develops when it is necessary to orientate the viewer along the axis "right $<\longrightarrow$ left", if there is a human figure depicted in the centre of the canvas (usually facing the viewer). In such cases there should be "a mirror reflection of space": for example, there is something on the right side of the picture (from the view-point of the person who is looking at the picture). Automatically (due to mirror reflection) this very something appears on the left hand side for the person in the picture (who is facing the viewer as if looking from the mirror). In describing such picture verbally the problem arises: which focalizer's position to choose as a reference point for such "left $\longrightarrow \longrightarrow$ right" axis? Should it be the central figure in the picture or the viewer? 
Our observations are the following: in most such cases, the "right $<\longrightarrow$ left" axis centeres upon the viewer of the picture choosing $\mathrm{him} / \mathrm{her}$ as the focalizer.

For example, Bernardo Strozzi's "Girl with a Viola da Gamba" depicts a young woman, with her right hand resting on the bureau, on which open notes and a violin lie. The annotation describes the picture like this: "the woman holds a Viola da gamba. Some books of music and a violin are on her left side".

The monumental canvas created by the 16th century painter Correggio for the altar in the city of Modena, has a pyramidal composition: in the center at the top there is the figure of Madonna and Child, on her right hand John the Baptist has knelt, St. George stands on her left. Reproduction of Correggio's "Madonna with St. George" is accompanied with annotation, which describes the location of the figures on the canvas from the perspective of the viewer: "the figure standing on the left hand side is John the Baptist.... on the right side, elegantly poising, is St. George ".

A thorough analysis of 59 catalogue entries revealed the only case of a "character" reference point for the axis "right $<\longrightarrow$ left". While describing Jan Wildens" "Winter Landscape with Huntsman ", the author of the annotation mentions some details focalizing them from the view point of the central figure of the hunter, saying about them: "On the right hand side only some closely seen bare trees and bushes appear", though the viewer sees these trees and bushes on the left side of the canvas. In this rare case the focalizer is the huntsman shown in the picture and not the viewer.

But the general tendency is obvious: word shifters (deictic words among them) in the text of the annotation of the museum catalogue are first of all oriented upon the optical focus of the reader-viewer. Together with other verbal means they aim at his/her involvement into a common spatial field which unites the user of the catalogue entry and the entry as it is, in both physical (in page space) and cognitive (in image space) perspectives.

This is the way cooperation of pictorial and verbal texts works in a museum catalogue. Their transformation of the former into the latter shows itself in specific variant of echphrasis. And their coexistence makes the essense of such publication as museum catalogue.

To summarize the observations made, let us say the following. Each item of the museum catalogue is a polycode semiotic complex that implements a variety of means and communication tactics to optimize the targeted activity of the catalogue user in both his/her communicative roles: as a reader and as a viewer. Clipping one of these roles (for example, the inability to read the annotations) significantly impoverishes not only the 
receptive, but also the cognitive activity of the user of the museum catalogue, as his/her thesaurus remains untouched (no additional information) and numerous clues and hints about what is shown remain undesiphered.

\section{CONCLUSIONS}

Summing up the performed investigation we come to the following conclusion. Both a pictorial and a verbal message possess the semiotic status of a text. Each of them has certain potential of coexisting side by side in a common polycode text, cooperating with each other and sometimes transforming into each other. Transformation might result either in visualization, i.e. turning a verbal text into a picture or, vice versa, verbalization of a pictorial message in echphrasis, i.e. verbal description and explanation of the form and/or content of the picture. Communicative impact of either of those combinations is certainly beneficial.

\section{SUMMARY}

The article highlights the problem of inter-code relations and transformations of two different types of messages: verbal and pictorial. We presume that: first, both a picture and a verbal message are texts; second, they can share a common message either functioning by itself each, or commenting each other, or transforming each other becoming equivalent reciprocal versions. Narrative painting is treated as a case of visual transformations, mainly of Biblical and mythological verbal texts. The opposite process i.e. transforming a pictorial text into its verbal description is regarded as echphrasis which may happen in different type of text (belles-lettres and academic writing). In a very specific way it functions in a polycode text of a museum catalogue. Coexistence, transformation and cooperation of of the discussed types of messages and their mutual impact upon the communicative result of polycode messages are analyzed on the material of illustrated texts, guide books, academic writing, the main emphasis is upon polycode text in a museum catalogue. The issue of addressee's different activities in the abovementioned types of polycode messages is touched upon as well.

\section{REFERENCES}

1. Колегаева И.М. Музейный каталог как вид поликодового текста. Записки з романогерманської філології. Випуск 1 (32). Одеса: КП ОМД, 2014. С. 92-101.

2. Колегаєва I.M. Полімодальність відчуттів у дзеркалі полікодовості тексту, або ще раз про антропоцентризм у лінгвістиці. 
Записки з романо-германської філології. Випуск 2 (35). Одеса: КП ОМД, 2015. С. 105-113.

3. Лотман Ю.М. Семиотика культуры и понятие текста. Структура и семиотика художественного текста. Труды по знаковым системам. Ученые записки Тартуского гос. университета. Тарту, 1981. Вып. 515. С. 3-7.

4. Моррис Ч.У. Основания теории знаков. Семиотика: Антология. Сост. Ю.С. Степанов. 2-е изд. испр. и доп. М.: Академический проект, 2001. С. 45-97.

5. Boddy-Evans M. Abstract Art: An Introduction. URL: http://painting.about.com/od/abstractart/a/abstract_art.htm

6. Leys S. The Hall of Uselessness: collected essays. e-Book: English/ 2012.: Collingwood, Vic.: Black Inc.

7. Masterpieces of Dresden. Picture Gallery "Old Masters". By H. Marx. Leipzig: E.A. Seeman, 1993. 62 p.

\section{Information about the author:} Kolegaeva I. M.,

Doctor of Philological Sciences, Professor, Head of the Chair of Lexicology and Stylistics of the English Language, Romance-Germanic Philology Department, Odesa I. I. Mechnikov National University 2, Dvoryanska str., Odesa, 65082, Ukraine 